\title{
The relationship between transformational leadership and work engagement. Moderated mediation roles of psychological ownership and belief in just world

\author{
Fullchis Nurtjahjani
} \\ tember 2021
}

Department of Business Administration, State Polytechnic of Malang, Malang, Indonesia

Ridolof Wenand Batilmurik

Department of Business Administration, State Polytechnic of Kupang, Kupang, Indonesia

Ayu Fury Puspita

Faculty of Economics and Business, Brawijaya University, Malang, Indonesia, and

Jappy Parlindungan Fanggidae

Department of Business Administration, State Polytechnic of Kupang,

Kupang, Indonesia

\begin{abstract}
Purpose - This study aims to investigate the mediating and moderating effects of psychological ownership and belief in just world in the relationship between transformational leadership and work engagement.

Design/methodology/approach - The data were collected from 183 lecturers who teach in an Indonesian university. The questionnaires covered transformational leadership, psychological ownership, belief in just world and work engagement. The collected data were examined with structural equation model analysis.

Findings - The results demonstrated a significant moderated mediation index, which indicated that the relationship between transformational leadership and work engagement is mediated by psychological ownership and is moderated by belief in just world.

Practical implications - To achieve higher work engagement, organizations should increase employees' feelings of ownership and boost just world belief.

Originality/value - The present study offers new insight on how personality trait plays a moderating role in the relationship between transformational leadership and work engagement.
\end{abstract}

Keywords Public sector, Transformational leadership, Work engagement, Psychological ownership, Belief in just world

Paper type Research paper

(C) Fullchis Nurtjahjani, Ridolof Wenand Batilmurik, Ayu Fury Puspita and Jappy Parlindungan Fanggidae. Published in Organization Management Journal. Published by Emerald Publishing Limited. This article is published under the Creative Commons Attribution (CC BY 4.0) licence. Anyone may reproduce, distribute, translate and create derivative works of this article (for both commercial and noncommercial purposes), subject to full attribution to the original publication and authors. The full terms of this licence maybe seen at http://creativecommons.org/licences/by/4.0/legalcode 
OMJ

19,2

\section{Introduction}

Employee work engagement is highly desirable for every leader. Engaged workers tend to have high levels of energy and enthusiasm and are happily immersed in doing their work (Bakker \& Leiter, 2017). In contrast with disengaged workers, engaged employees are willing to work harder voluntarily to achieve positive outcomes for the organization (Bakker, 2011). Furthermore, engaged workers can spread a positive working atmosphere to their surroundings, including to their colleagues, management, and in general, to the organization's stakeholders. Therefore, studies on antecedents of employees work engagement is equally essential as studies on employees negative organizational behavior, such as employees burnout (Burić \& Macuka, 2018; Dai, Altinay, Zhuang, \& Chen, 2021) or employees turnover intention (Pitts, Marvel, \& Fernandez, 2011).

Research on antecedents of work engagement has enjoyed ample of attention from scholars (Burić \& Macuka, 2018; Joo, Lim, \& Kim, 2016; Schaufeli, Salanova, GonzálezRomá, \& Bakker, 2002) where one of the most studied constructs is transformation leadership (Salanova, Lorente, Chambel, \& Martínez, 2011; Zhu, Avolio, \& Walumbwa, 2009). Since transformational leadership and work engagement are grouped as positive organizational behavior (POB), the association between the two is plausible. Nonetheless, the findings from a prior study on the relationship between the two constructs suggest that more studies are needed to investigate the possible mediators of the connection (Zhu et al., 2009). In line with that, Ghadi, Fernando and Caputi (2013) contend that the relationship between the two can be more well-understood if additional mediators or moderators are proposed in the research model. We intend to fill this gap by proposing a mediator (i.e. psychological ownership) and a moderator (i.e. belief in just world) in the relationship between transformational leadership and work engagement.

By examining psychological ownership as a mediator and belief in just world as a moderator in the relationship, we expect to contribute to the literature both theoretically and practically. Theoretically, the present study responds to calls from prior studies (Ghadi et al., 2013; Zhu et al., 2009) regarding the need to present mediators and moderators in the relationship between transformational leadership and work engagement. Practically, this study recommends the importance of psychological ownership and belief in just world in enhancing work engagement. We found that transformational leaders can elevate psychological ownership, which subsequently increases work engagement only if employees believe that the world is just. Considering that engaged employees to their work are relatively rare (Ghadi et al., 2013), organizations may attempt to boost employees work engagement in various ways. Our findings could be the answer to this managerial problem.

\section{Literature review}

\section{Transformational leadership and work engagement}

Transformational leadership is one of the most important theories in the area of organizational behavior in the past few decades (Wright, Moynihan, \& Pandey, 2012). In contrast to transactional leaders who typically motivate the subordinates to perform in the correct and expected way, transformational leaders inspire the followers to do beyond what is usually expected (Kark, Van Dijk, \& Vashdi, 2018). In doing so, transformational leaders increase their employees' awareness regarding the importance of achieving organizational objectives. An effective way to do that is by aligning the needs of the employees with the needs of the organization and its stakeholders' (Wright et al., 2012).

Transformational leaders tend to promote and maintain closer relationships with employees by minimizing power distance between them and focusing on the employees' needs and capabilities (Puni, Mohammed, \& Asamoah, 2018). This relationship is built on 
mutual trust between the leader and the subordinate in which frankness and richness of the communication, as well as feedbacks between them, are guaranteed (Salanova et al., 2011). In this excellent working environment, the leaders and the employees collaboratively attempt to help the organization to achieve its goals. Cheng et al. (2012) argued that in general transformational leadership may influence employees' positive attitudes and behavior. Transformational leadership has been positively associated with employees' performance, job satisfaction and organizational commitment (Eliyana \& Ma'arif, 2019).

Work engagement is defined as "a positive, fulfilling, work-related state of mind that is characterized by vigor, dedication, and absorption” (Schaufeli et al., 2002, p. 74). In other words, highly engaged employees are highly passionate in doing their job and are often deeply immersed in their work (Bakker \& Leiter, 2017). This is because work engagement is an implementation of intrinsic motivation, which is moved by the enjoyment and enthusiasm in doing a particular job (Putra et al., 2017). Given its positive impacts on the organization, employee work engagement is highly desirable by leaders. Thus, typical transformational leaders attempt to inspire employees to be more engaged to their work. In support to this argument, Ghadi et al. (2013) found that transformation leadership indirectly affects employees work engagement through a positive attitude (i.e. meaning of work).

Transformational leadership and psychological ownership. Psychological ownership refers to a state where individuals feel that they possess the target of ownership, including physical and non-physical materials. In the literature, the psychological ownership concept has developed from a rather broad scope concerned with possession and property to the context of organizational psychological ownership (Dawkins, Tian, Newman, \& Martin, 2017). The feeling of ownership, including toward an organization, is a part of human beings, affecting individuals' behavior, emotion and psychological condition. Furthermore, the essence of psychological ownership is the possessiveness and being merged to the object (material or immaterial), which leads the individual to establish the object as a part of their identity (Pierce, Kostova, \& Dirks, 2001). In an organizational context, psychological ownership refers to psychologically experienced conditions where employees establish possessive feelings for the organization (Van Dyne \& Pierce, 2004).

As a part of POB, psychological ownership has a sense of positivity and eagerness to success, as well as openness to change and development (Avey et al., 2009). Employees with high psychological ownership for the organization perform better in their jobs and have less intention to conduct deviant behaviors (Kim \& Beehr, 2017). They also have higher organizational commitment, job satisfaction and organizational-based self-esteem. In addition, ownership feelings are associated with empowerment, since empowered employees are often aware that they have autonomy and control over their organization (Van Dyne \& Pierce, 2004). It is then reasonable that an empowering leader would attempt to increase psychological ownership among his or her employees to achieve positive outcomes for the organization (Kim \& Beehr, 2017). Based on the review, we propose our first hypothesis as follows:

H1. There is a positive relationship between transformational leadership and psychological ownership.

Belief in just world as a moderator between psychological ownership and work engagement. Pierce et al. (2001) identified three routes of how employees establish the feeling of psychological ownership toward their organization. They are controlling the organization, knowing the organization intimately and investing the self into the organization. These three mechanisms support the idea that employees with high psychological ownership for the organization would boost their work engagement. For instance, when employees 
OMJ 19,2

believe their work and institution as possessions, their feeling of responsibility toward the success of the institution increases. Therefore, they will intensify their efforts to help the organization (Kim \& Beehr, 2017). Also, the feeling of control over the organization through a participative decision-making process increases psychological ownership and subsequently generates positive outcomes (Liu et al., 2012).

Recent research showed that psychological ownership interacts with another factor (i.e. promotion focus) in influencing work engagement (Dai et al., 2021). This indicates that there are conditions when other factors moderate the relationship between psychological ownership and work engagement. We argue that belief in just world moderates the relationship. Belief in just world or the just world hypothesis contends that people believe that the world is just and in general people get what they deserve, enabling them to consider the world as a stable and orderly place (Lerner \& Miller, 1978). For example, people who have done positive behaviors deserve positive outcomes while those who have committed negative behaviors deserve negative outcomes (Hafer \& Rubel, 2015).

People who personally identify themselves with an organization hold a high feeling of psychological ownership (Avey et al., 2009). In an organization, these employees may feel that the ups and downs of the organization depend on them, meaning that they have control over the organization to some extent (Pierce et al., 2001). In practice, if employees conduct positive behavior for the organization, the organization would perform better or contrariwise. The principles of deservingness and fairness play an essential part in shaping one's behaviors here. Without these principles, even the feelings of psychological ownership would find difficulties to produce positive behavior towards the organization.

We propose that the link between psychological ownership and work engagement depends on the levels of belief in just world. That is, when employees have high psychological ownership for the organization, if they believe the world is just, compared with those who do not, they tend to have a higher willingness to engage in their jobs. Employees who are attached to the organization and believe in the principle of "deservingness" would engage more in their work because they believe that the success or failure of the organization depends on them. In contrast, employees with low belief in just world would consider that they have little or no effect on organizational outcomes. However, this effect is not relevant to employees with low psychological ownership of the organization. They would have a lower tendency to engage in their work regardless of their levels of belief in just world. Formally, we hypothesize as follows:

H2. Belief in a just world will moderate the relationship between psychological ownership and work engagement, such that the higher the belief in a just world, the stronger the relationship between psychological ownership and work engagement.

\section{Indirect effect of transformational leadership on work engagement}

The relation between transformational leadership and work engagement has been well established in the literature (Ghadi et al., 2013). When transformational leaders show genuine attention to each employee, they tend to build a positive relationship with each other and a sense of belonging to the institution (Zhu et al., 2009). These feelings of ownership toward the organization would increase work engagement since the employee with higher psychological ownership will consider the institution as the place they belong to for a long time (Dai et al., 2020). Nonetheless, such a relationship between psychological ownership and work engagement depends on the principles of deservingness and fairness as indicated in belief in just world theory (Lerner \& Miller, 1978). That is when employees believe the world is just, the relationship between psychological ownership and work 
engagement is stronger. They are more likely to engage with work because they believe that they have some extent of control over the institution as their extended self.

In overall, by reviewing at the relationship among transformational leadership, psychological ownership, belief in a just world and work engagement, we hypothesize the following:

H3. Belief in a just world will moderate the relationship between transformational leadership and work engagement via psychological ownership. The mediated relationship is stronger when the belief in a just world is higher.

\section{Methods}

The present study used a cross-sectional survey to examine the connection between transformational leadership and work engagement. In so doing, a quantitative approach was used by conducting statistical analyzes to depict the relationships among constructs.

\section{Respondents and procedure}

The population of this study are faculty members in an Indonesian university. A convenience sampling method was used to select the available study respondents. In total, 484 lecturers were invited to participate in the study, however, only 183 complete responses received or yielded in $35.6 \%$ response rate. An invitation to participate with a questionnaire link was sent to lecturers via instant messaging services and emails, followed by a notification to ensure that the potential participants have received the invitation. This data collection method is one of the best ways to reach respondents quickly and at a low cost (Dillman, Smyth, \& Christian, 2014). Data were collected during the period of May 2020-July 2020. The participants were informed that the study is completely anonymous, therefore, they are encouraged to give their honest answers throughout the survey. The data collection procedure and materials have been approved by an institutional review board.

The data were collected from faculty members in an Indonesian university. Studies examining transformational leadership in educational institutions are rare despite the importance to practice the type of leadership in the institutions (Al-Mansoori \& Koç, 2019). Transformational leadership is considered the solution to eradicating conservatism and exclusiveness in universities in this dynamic world (Brandis, 2003).

\section{Measures}

All scales used in this study are adapted from previous relevant studies. The use of prior established measures is more preferred considering the complexity of developing new measures (Fowler, 2013). All items are measured based on a five-point Likert scale ranging from 1 (strongly disagree) to 5 (strongly agree).

Transformational leadership. The scale was measured with a short measure of transformational leadership developed by Carless, Wearing and Mann (2000). The scale consists of seven items. Sample questions are: "The leader communicates a clear and positive vision of the future", and "The leader fosters trust, involvement and cooperation among team members."

Psychological ownership. Psychological ownership was assessed with a three-item developed by Han, Chiang and Chang (2010). The questions are as follows:

- I feel this institution is mine;

- I feel closely involved in the success or failure of the institution; and

- I am willing to treat this institution as my home. 
$\mathrm{OMJ}$

19,2

Belief in just world. We measured just world belief with seven items based on the study by Lipkus (1991). The sample questions are: "I feel that people get what they are entitled to have", "I feel that people earn the rewards and punishments they get", and "I feel that people get what they deserve."

Work engagement. A short work engagement questionnaire from Schaufeli, Bakker and Salanova (2006) was adapted in this study. The scale consists of nine items. The sample questions are: "I am enthusiastic about my job", "When I get up in the morning, I feel like going to work", and "I am proud of the work that I do."

\section{Results}

Demographic profile

In total, 183 faculty members participated in this study. Analysis of the respondents' demographic data demonstrated that most of them were men (70\%). Their age ranged from 31 to 63 years old, with an average of 43 years $(\mathrm{SD}=7.78)$. Most of the respondents $(92 \%)$ have more than 10 years of experience as lecturers.

\section{Measurement model}

The instruments used in this study were assessed in terms of convergent validity, internal consistency reliability and discriminant validity. First, convergent validity was assessed by inspecting loading factors and average variance extracted (AVE). The suggested cut-off value of the loading factor in the research model is a minimum of 0.708 and the AVE value is at least 0.50 (Hair et al., 2016). Our results, as seen in Table 1, indicate a good convergent validity of the items.

Second, internal consistency for the reliability of the measurement model is measured by inspecting the Cronbach alpha and Composite Reliability (CR)values (Fornell \& Larcker, 1981). Table 1 shows that the Cronbach alpha $(\alpha)$ and CR values exceed the lower threshold of 0.70 as suggested (Hair et al., 2016). Thus, the variables in this study are considered sufficiently reliable. There are different consensus regarding the maximum acceptable values of Cronbach alpha. While alpha values ranging from 0.70-0.95 are accepted (Tavakol \& Dennick, 2011), others consider the range of $0.58-0.97$ as satisfactory (Taber, 2018). It is noted that a high value of alpha does not imply that the scale is unidimensional, rather it may indicate redundancy in the items.

Third, to test discriminant validity, we examined the values of the square root of AVE and the heterotrait-monotrait ratio of correlation (HTMT). To meet a good discriminant validity, the square root of the AVE for each variable must be higher than the correlation between the variable and other variables in the model (Fornell \& Larcker, 1981). Also, the value of the HTMT ratio should be less than 0.90 (Henseler et al., 2015). As illustrated in Table 2 , the abovementioned requirements have been met.

Common method bias was tested in the data. The results of the study are obtained based on self-report and cross-sectional data, which could suffer from potential bias problems (Putra et al., 2017). Kock (2015) suggests that the occurrence of variance inflation factors (VIFs) greater than 0.3 indicates the presence of common method bias in the model. As seen in the Table 3, the model is considered free from common method bias since all the VIF values are higher than 0.3 .

\section{Moderated mediation model}

The present study's objective is to examine the direct and indirect effects of transformational leadership on employees' work engagement and the mediating role of 


\begin{tabular}{|c|c|c|c|c|c|}
\hline Variable & Loading & $\alpha$ & $\mathrm{CR}$ & AVE & $\begin{array}{l}\text { Moderated } \\
\text { mediation }\end{array}$ \\
\hline Transformational leadership (TL) & & 0.93 & 0.95 & 0.73 & \\
\hline TL1 & 0.79 & & & & \\
\hline$T L 2$ & 0.93 & & & & \\
\hline$T L 3$ & 0.88 & & & & \\
\hline TL4 & 0.87 & & & & \\
\hline TL5 & 0.86 & & & & 53 \\
\hline$T L 6$ & 0.86 & & & & \\
\hline$T L 7$ & 0.88 & & & & \\
\hline Psychological ownership (PO) & & 0.84 & 0.90 & 0.76 & \\
\hline$P O 1$ & 0.87 & & & & \\
\hline PO2 & 0.93 & & & & \\
\hline PO3 & 0.82 & & & & \\
\hline Belief in just world (BJW) & & 0.96 & 0.96 & 0.80 & \\
\hline$B J W 1$ & 0.94 & & & & \\
\hline BJW2 & 0.81 & & & & \\
\hline BJW3 & 0.91 & & & & \\
\hline BJW4 & 0.93 & & & & \\
\hline BJW5 & 0.93 & & & & \\
\hline BJW6 & 0.94 & & & & \\
\hline BJW7 & 0.84 & & & & \\
\hline Work-engagement & & 0.94 & 0.95 & 0.69 & \\
\hline WE1 & 0.79 & & & & \\
\hline WE2 & 0.83 & & & & \\
\hline WE3 & 0.81 & & & & \\
\hline WE4 & 0.88 & & & & \\
\hline WE5 & 0.83 & & & & \\
\hline WE6 & 0.87 & & & & \\
\hline WE7 & 0.88 & & & & \\
\hline WE8 & 0.72 & & & & Table 1. \\
\hline WE9 & 0.86 & & & & Measurement model \\
\hline
\end{tabular}

\begin{tabular}{lcccc}
\hline Variables & TL & PO & BJW & WE \\
\hline$T L$ & $(0.85)$ & 0.37 & 0.52 & 0.28 \\
$P O$ & $0.33^{* *}$ & $(0.87)$ & 0.13 & 0.27 \\
$B J W$ & $0.50^{*}$ & 0.09 & $(0.89)$ & 0.18 \\
$W E$ & $0.27^{* *}$ & $0.23^{* *}$ & $0.17^{*}$ & $(0.83)$
\end{tabular}

Notes: Diagonal values (in the brackets) are the square root of AVE, values below the diagonal are correlations between variables, values above the diagonal are HTMT ratio

Table 2. Discriminant validity

psychological ownership. Also, this study investigates the moderating role of belief in just world in the relationship. In order T to achieve these goals, the moderated mediation model is tested (Process Model 14; 5,000 resamples; Hayes, 2013). First, the effect of transformational leadership on psychological ownership was positive and significant $(b=0.33, S E=0.07, p<$ 0.001). This supports our first hypothesis. However, the direct effect of transformational leadership on employees work engagement was insignificant $(b=0.10, S E=0.08, p=0.24)$.

Second, the moderating effect of belief in just world in the association between psychological ownership and work engagement was inspected. The results demonstrated that both psychological ownership $(b=0.77, S E=0.26, p<0.01)$ and belief in just world 
OMJ

19,2

54

$(b=0.85, S E=0.25, p<0.01)$ affected work engagement. More importantly, the interaction between psychological ownership and belief in just world in affecting work engagement was significant $(b=0.23, S E=0.06, p<0.001)$. The results support the second hypothesis. In addition, the moderation pattern is observed by conducting a simple slope analysis (Aiken et al., 1991). As illustrated in Figure 1, when belief in just world was lower the relationship between psychological ownership and work engagement was weakened. In contrast, when employees have a higher belief in just world, the relation between psychological ownership and work engagement was stronger.

Third, the significant moderated mediation index indicated that the association between transformational leadership and work engagement is mediated by psychological ownership and is moderated by belief in just world $(b=0.07, S E=0.04,95 \% \mathrm{CI}=[0.01,0.16])$. The results support our third hypothesis, as illustrated by Figure 2.

\section{Discussion}

As predicted, the results supported the developed hypotheses in this study. First, the direct relationship between transformational leadership and psychological ownership was positive and significant. This indicates that good transformational leadership from management can

Table 3.

Common method bias

\begin{tabular}{lcccc}
\hline Variables & TL & PO & BJW & WE \\
\hline$T L$ & - & 1.518 & 1.241 & 1.550 \\
$P O$ & 1.062 & - & 1.205 & 1.134 \\
$B J W$ & 1.036 & 1.426 & - & 1.393 \\
$W E$ & 1.083 & 1.101 & 1.123 & - \\
Note: All values are VIFs & & & & \\
\hline
\end{tabular}

Figure 1.

Moderating role of belief in just world

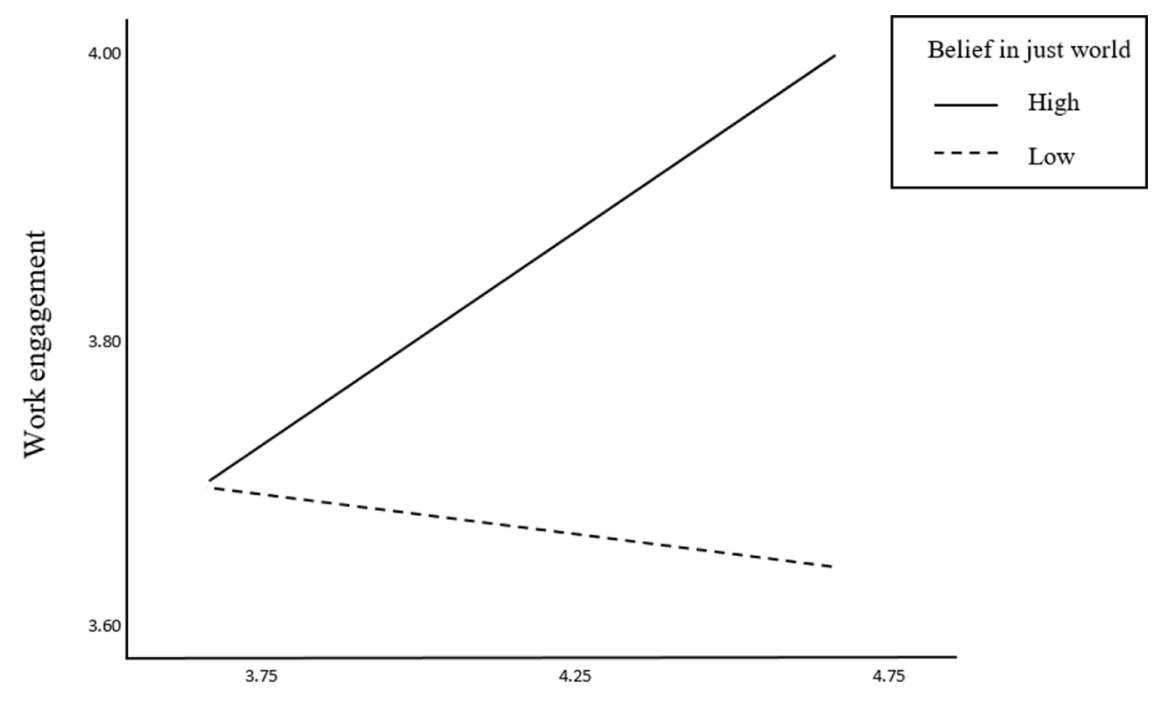

Psychological ownership 
enhance employees feeling of ownership for the organization. The result is consistent with previous studies investigating such relationships in public sector employees (Park, Song, Yoon, \& Kim., 2013) and private sector employees (Ghafoor, Qureshi, Khan, \& Hijazi, 2011). Second, the moderating role of belief in just world in the relationship between psychological ownership and work engagement was supported in the data. Employees with high psychological ownership showed a higher tendency to engage in their work only if they believe in just world principles. In contrast, when belief in just world was low, the relationship between psychological ownership and work engagement was diminished. Finally, it was found that psychological ownership mediated the relationship between transformational leadership and work engagement as moderated by belief in just world.

Research has shown that belief in just world is positively correlated with an internal locus of control (Furnham \& Procter, 1989), a belief that events in one's life are consequences of his/her behaviors or aptitudes (Donat, Peter, Dalbert, \& Kamble, 2016). In this regard, one may assume that the internal locus of control overlaps with belief in just world in our findings. However, despite the similarities, there is a slight distinction between the two constructs. That is, just world believers are less autonomous and less independent than people who believe in internal locus of control. Unlike internal locus of control believers who solely put confidence in themselves (Donat et al., 2016), just world believers consider that the world is ruled by external forces (Steensma et al., 1994). In our study context, we consider belief in just world as an appropriate construct since the study respondents, faculty members in Indonesia, mostly believe in external forces (i.e. religious) (Adi \& Adawiyah, 2018).

Relationships among the variables in the research model can direct managers to implement policies regarding the need to have engaged employees in organizations. The findings indicate that high work engagement can be achieved by increasing transformational leadership capabilities and psychological ownership. Human resource training can be conducted to achieve these goals (Nielsen \& Cleal, 2011), which can eventually reduce the cost incurred by organizations for having disengaged employees.

Given the importance of belief in just world in increasing work engagement, management should establish and maintain the principles of fairness and deservingness in the institution. Cheng et al. (2020) argue that fair treatment by leaders might increase employees' justice belief in the workplace. Although belief in just world is considered as an unchangeable personality trait, others contend that it may be influenced by personal experience and attitudes since justice judgments are subjective in nature (Dalbert \& Stoeber, 2006). In practice, a screening procedure can be applied to identify employees' levels of belief in just world in the institution before building a communication showing how the institution implements fairness and justice in its operations.

\section{Limitation and future research}

The present study has limitations. First, the non-probability convenience sampling strategy implemented in this study could suffer from sampling bias as it may not portray the target

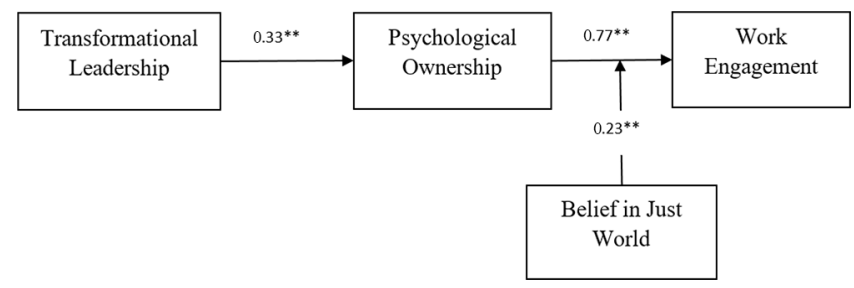

Figure 2. Moderated mediation model 
population (Etikan, Musa, \& Alkassim, 2016). Second, this is a cross-sectional study where the results can only describe the situation when the data was collected (Levin, 2006). Future studies can resolve these issues by conducting a probability sampling strategy and using time series data. Third, leadership in higher education must embrace the interests of students, faculty members, funders and stakeholders given high competition in meeting societies' needs (Al-Mansoori \& Koç, 2019). Consequently, higher education leaders are expected to show unique transformational leadership compared with leadership in other types of organizations. Thus, the results of the study may not be sufficient to represent the circumstances in different organizations.

Finally, the data were collected among public servants in Indonesia where the profession is considered as having career safety and social respect from the community. A recent study confirmed that despite having a high workload and job burnout, public sector employees did not intend to leave their jobs (Dwinijanti, Adhikara, Kusumapradja, \& PPs, 2020). This might have led our respondents to show high psychological ownership even in the condition where management demonstrates less transformational leadership. Future studies may address this problem by including employees from both public and private sectors to observe differences between the two groups.

\section{References}

Adi, P. H. \& Adawiyah, W. R. (2018). The impact of religiosity, environmental marketing orientation and practices on performance. Journal of Islamic Marketing.

Aiken, L. S., West, S. G., \& Reno, R. R. (1991). Multiple regression: Testing and interpreting interactions, Sage.

Al-Mansoori, R. S. \& Koç, M. (2019). Transformational leadership, systems, and intrinsic motivation impacts on innovation in higher education institutes: Faculty perspectives in engineering colleges. Sustainability, 11(15), 4072 doi: 10.3390/su11154072.

Avey, J. B., Avolio, B. J., Crossley, C. D., \& Luthans, F. (2009). Psychological ownership: Theoretical extensions, measurement and relation to work outcomes. Journal of Organizational Behavior, 30(2), 173-191. doi: 10.1002/job.583.

Bakker, A. B. (2011). An evidence-based model of work engagement. Current Directions in Psychological Science, 20(4), 265-269. doi: 10.1177/0963721411414534.

Bakker, A. B. \& Leiter, M. (2017). Strategic and proactive approaches to work engagement. Organizational Dynamics, 46(2), 67-75. doi: 10.1016/j.orgdyn.2017.04.002.

Brandis, B. (2003). Transformational leadership in higher education: from politics to porcelain.

Burić, I. \& Macuka, I. (2018). Self-efficacy, emotions and work engagement among teachers: a two wave cross-lagged analysis. Journal of Happiness Studies, 19(7), 1917-1933. doi: 10.1007/s10902-017-9903-9.

Carless, S. A., Wearing, A. J., \& Mann, L. (2000). A short measure of transformational leadership. Journal of Business and Psychology, 14(3), 389-405. doi: 10.1023/A:1022991115523.

Cheng, Y.-N., Yen, C.-L., \& Chen, L. H. (2012). Transformational leadership and job involvement: the moderation of emotional contagion. Military Psychology, 24(4), 382-396. doi: 10.1080/08995605.2012.695261.

Cheng, Y., Nudelman, G., Otto, K., \& Ma, J. (2020). Belief in a just world and employee voice behavior: the mediating roles of perceived efficacy and risk. The Journal of Psychology, 154(2), 129-143. doi: 10.1080/00223980.2019.1670126.

Dai, Y.-D., Altinay, L., Zhuang, W.-L., \& Chen, K.-T. (2021). Work engagement and job burnout? Roles of regulatory foci, supervisors' organizational embodiment and psychological ownership. Journal of Hospitality and Tourism Management, 46, 114-122. doi: 10.1016/j.jhtm.2020.12.001.

Dai, Y.-D., Zhuang, W.-L., Lu, S.-C., \& Huan, T.-C. (2020). Work engagement or job burnout? Psychological ownership amongst the employees of international tourist hotels. Tourism Review. 
Dalbert, C. \& Stoeber, J. (2006). The personal belief in a just world and domain-specific beliefs about justice at school and in the family: a longitudinal study with adolescents. International Journal of Behavioral Development, 30(3), 200-207. doi: 10.1177/0165025406063638.

Dawkins, S., Tian, A. W., Newman, A., \& Martin, A. (2017). Psychological ownership: a review and research agenda. Journal of Organizational Behavior, 38(2), 163-183. doi: 10.1002/job.2057.

Deci, E. L. \& Ryan, R. M. (1985). Conceptualizations of intrinsic motivation and self-determination. Intrinsic motivation and self-determination in human behavior (pp. 11-40), Springer.

Dillman, D. A., Smyth, J. D., \& Christian, L. M. (2014). Internet, phone, mail, and mixed-mode surveys: the tailored design method, John Wiley \& Sons.

Donat, M., Peter, F., Dalbert, C., \& Kamble, S. V. (2016). The meaning of students' personal belief in a just world for positive and negative aspects of school-specific well-being. Social Justice Research, 29(1), 73-102. doi: 10.1007/s11211-015-0247-5.

Dwinijanti, L., Adhikara, M. A., Kusumapradja, R., \& PPs, M. (2020). Job satisfaction and turnover intention among public sector nurses: is workload and burnout the issue? JEMA: Jurnal Ilmiah Bidang Akuntansi Dan Manajemen, 17(1), 67-77. doi: 10.31106/jema.v17i1.4951.

Eliyana, A. \& Ma'arif, S. (2019). Job satisfaction and organizational commitment effect in the transformational leadership towards employee performance. European Research on Management and Business Economics, 25(3), 144-150.

Etikan, I., Musa, S. A., \& Alkassim, R. S. (2016). Comparison of convenience sampling and purposive sampling. American Journal of Theoretical and Applied Statistics, 5(1), 1-4. doi: 10.11648/j. ajtas.20160501.11.

Fornell, C. \& Larcker, D. F. (1981). Evaluating structural equation models with unobservable variables and measurement error. Journal of Marketing Research, 18(1), 39-50. doi: 10.1177/ 002224378101800104.

Fowler, F. J.Jr (2013). Survey research methods, Sage publications.

Furnham, A. \& Procter, E. (1989). Belief in a just world: Review and critique of the individual difference literature. British Journal of Social Psychology, 28(4), 365-384. doi: 10.1111/j.2044-8309.1989. tb00880.x.

Ghadi, M. Y., Fernando, M., \& Caputi, P. (2013). Transformational leadership and work engagement: the mediating effect of meaning in work. Leadership \& Organization Development Journal,

Ghafoor, A., Qureshi, T. M., Khan, M. A., \& Hijazi, S. T. (2011). Transformational leadership, employee engagement and performance: Mediating effect of psychological ownership. African Journal of Business Management, 5(17), 7391-7403.

Hafer, C. L. \& Rubel, A. N. (2015). The why and how of defending belief in a just world. Advances in experimental social psychology, Vol. 51, pp. 41-96. Elsevier.

Hair, J. F., Jr, Hult, G. T. M., Ringle, C., \& Sarstedt, M. (2016). A primer on partial least squares structural equation modeling (PLS-SEM, Sage publications.

Han, T.-S., Chiang, H.-H., \& Chang, A. (2010). Employee participation in decision making, psychological ownership and knowledge sharing: mediating role of organizational commitment in taiwanese high-tech organizations. The International Journal of Human Resource Management, 21(12), 2218-2233. doi: 10.1080/09585192.2010.509625.

Hayes, A. F. (2013). Introduction to mediation, moderation, and conditional process analysis a regression-based approach, Guilford Press.

Henseler, J., Ringle, C. M., \& Sarstedt, M. (2015). A new criterion for assessing discriminant validity in variance-based structural equation modeling. Journal of the Academy of Marketing Science, 43(1), 115-135. doi: 10.1007/s11747-014-0403-8.

Joo, B.-K., Lim, D. H., \& Kim, S. (2016). Enhancing work engagement. Leadership \& Organization Development Journal, 37(8) doi: 10.1108/LODJ-01-2015-0005. 
$\mathrm{OMJ}$ 19,2

Kark, R., Van Dijk, D., \& Vashdi, D. R. (2018). Motivated or demotivated to be creative: the role of selfregulatory focus in transformational and transactional leadership processes. Applied Psychology, 67(1), 186-224. doi: 10.1111/apps.12122.

Kim, M. \& Beehr, T. A. (2017). Self-efficacy and psychological ownership mediate the effects of empowering leadership on both good and bad employee behaviors. Journal of Leadership \& Organizational Studies, 24(4), 466-478. doi: 10.1177/1548051817702078.

Kock, N. (2015). Common method bias in PLS-SEM: a full collinearity assessment approach. International Journal of e-Collaboration (e-Collaboration), 11(4), 1-10. doi: 10.4018/ijec.2015100101.

Lerner, M. J. \& Miller, D. T. (1978). Just world research and the attribution process: Looking back and ahead. Psychological Bulletin, 85(5), 1030 doi: 10.1037/0033-2909.85.5.1030.

Levin, K. A. (2006). Study design III: Cross-sectional studies. Evidence-Based Dentistry, 7(1), 24-25. doi: 10.1038/sj.ebd.6400375.

Lipkus, I. (1991). The construction and preliminary validation of a global belief in a just world scale and the exploratory analysis of the multidimensional belief in a just world scale. Personality and Individual Differences, 12(11), 1171-1178. doi: 10.1016/0191-8869(91)90081-L.

Liu, J., Wang, H., Hui, C., \& Lee, C. (2012). Psychological ownership: How having control matters. Journal of Management Studies, 49(5), 869-895. doi: 10.1111/j.1467-6486.2011.01028.x.

Nielsen, K. \& Cleal, B. (2011). Under which conditions do Middle managers exhibit transformational leadership behaviors? - an experience sampling method study on the predictors of transformational leadership behaviors. The Leadership Quarterly, 22(2), 344-352. doi: 10.1016/j. leaqua.2011.02.009.

Park, C. H., Song, J. H., Yoon, S. W., \& Kim, J. (2013). A missing link: psychological ownership as a mediator between transformational leadership and organizational citizenship behaviour. Human Resource Development International, 16(5), 558-574. doi: 10.1080/13678868.2013.839510.

Pierce, J. L., Kostova, T., \& Dirks, K. T. (2001). Toward a theory of psychological ownership in organizations. Academy of Management Review, 26(2), 298-310. doi: 10.5465/amr.2001.4378028.

Pitts, D., Marvel, J., \& Fernandez, S. (2011). So hard to say goodbye? Turnover intention among US federal employees. Public Administration Review, 71(5), 751-760. doi: 10.1111/j.15406210.2011.02414.x.

Puni, A., Mohammed, I., \& Asamoah, E. (2018). Transformational leadership and job satisfaction: the moderating effect of contingent reward. Leadership \& Organization Development Journal, 39(4) doi: 10.1108/LODJ-11-2017-0358.

Putra, E. D., Cho, S., \& Liu, J. (2017). Extrinsic and intrinsic motivation on work engagement in the hospitality industry: Test of motivation crowding theory. Tourism and Hospitality Research, 17(2), 228-241. doi: 10.1177/1467358415613393.

Salanova, M., Lorente, L., Chambel, M. J., \& Martínez, I. M. (2011). Linking transformational leadership to nurses' extra-role performance: the mediating role of self-efficacy and work engagement. Journal of Advanced Nursing, 67(10), 2256-2266. doi: 10.1111/j.1365-2648.2011.05652.x.

Schaufeli, W. B., Bakker, A. B., \& Salanova, M. (2006). The measurement of work engagement with a short questionnaire: a cross-national study. Educational and Psychological Measurement, 66(4), 701-716. doi: $10.1177 / 0013164405282471$.

Schaufeli, W. B., Salanova, M., González-Romá, V., \& Bakker, A. B. (2002). The measurement of engagement and burnout: a two sample confirmatory factor analytic approach. Journal of Happiness Studies, 3(1), 71-92. doi: 10.1023/A:1015630930326.

Steensma, H., den Hartigh, E., \& Lucardie, E. (1994). Social categories, just world belief, locus of control, and causal attributions of occupational accidents. Social Justice Research, 7(3), 281-299. doi: 10.1007/BF02334835.

Taber, K. S. (2018). The use of Cronbach's alpha when developing and reporting research instruments in science education. Research in Science Education, 48(6), 1273-1296. doi: 10.1007/s11165-016-9602-2. 
Tavakol, M. \& Dennick, R. (2011). Making sense of cronbach's alpha. International Journal of Medical Education, 2, 53 doi: 10.5116/ijme.4dfb.8dfd.

Van Dyne, L. \& Pierce, J. L. (2004). Psychological ownership and feelings of possession: Three field studies predicting employee attitudes and organizational citizenship behavior. Journal of Organizational Behavior, 25(4), 439-459. doi: 10.1002/job.249.

Wright, B. E., Moynihan, D. P., \& Pandey, S. K. (2012). Pulling the levers: Transformational leadership, public service motivation, and mission valence. Public Administration Review, 72(2), 206-215. doi: 10.1111/j.1540-6210.2011.02496.x.

Zhu, W., Avolio, B. J., \& Walumbwa, F. O. (2009). Moderating role of follower characteristics with transformational leadership and follower work engagement. Group \& Organization Management, 34(5), 590-619. doi: 10.1177/1059601108331242.

\section{Corresponding author}

Fullchis Nurtjahjani can be contacted at: fullchis@polinema.ac.id

For instructions on how to order reprints of this article, please visit our website: 